\title{
Analysis of Design Wind Speed Distribution of Taiwan Area
}

Jing-Jong Jang

Associate Professor, Department of Harbor and River Engineering, National Taiwan Ocean University, Keelung, Taiwan, R.O.C.

Jeng-Ru Lee

Graduate Student, Department of Harbor and River Engineering, National Taiwan Ocean Universiry, Keelung, Taiwan, R.O.C.

Follow this and additional works at: https://jmstt.ntou.edu.tw/journal

Part of the Civil and Environmental Engineering Commons

\section{Recommended Citation}

Jang, Jing-Jong and Lee, Jeng-Ru (1997) "Analysis of Design Wind Speed Distribution of Taiwan Area," Journal of Marine Science and Technology. Vol. 5: Iss. 1, Article 7.

DOI: $10.51400 / 2709-6998.2538$

Available at: https://jmstt.ntou.edu.tw/journal/vol5/iss1/7

This Research Article is brought to you for free and open access by Journal of Marine Science and Technology. It has been accepted for inclusion in Journal of Marine Science and Technology by an authorized editor of Journal of Marine Science and Technology. 


\section{Analysis of Design Wind Speed Distribution of Taiwan Area}

Acknowledgements

The authors would like to thank the National Science Council for its support of this research (NSC 84-2211-E-019-001) 


\title{
ANALYSIS OF DESIGN WIND SPEED DISTRIBUTION OF TAIWAN AREA
}

\author{
Jing-Jong Jang* and Jeng-Ru Lee**
}

Keywords: Wind Speed, Probability Distribution Model, Building Code.

\begin{abstract}
This paper thoroughly examines the basic design wind speed according to wind loading of building codes in Taiwan. The first part of this study contains Chi-Square test and K-S (KolmogorovSmirnov) test on four common wind speed probability distribution models. The data to be tested are sampled from the annual maximum 10-minute average wind speed recorded by 25 weather stations of Taiwan Central Weather Bureau during the period from 1951 to 1990 . The Type I Extreme Value model is determined and recommended as the best wind speed probability distribution model for Taiwan area. This paper then explores the probability of exceedance of basic design wind speed within 50 years in Taiwan by exceedance probability theory and moment method. The results are compiled to develop the prelimmary design wind speed distribution maps of Taiwan area with 50-year return period to provide useful information for structure engineer in determining wind loading and modifying Taiwan's building codes in the future.
\end{abstract}

\section{INTRODUCTION}

Wind speed is a random variable which is affected by lots of factors such as geometric shapes, roughness, and elevations of ground surface. Therefore, the easiest and most direct means of obtaining wind speed distribution in different locations is to set up a measurement station at each location. However, the way how the anemometer reading will heavily influences wind speed record. The wind speed of short recording time usually higher than the wind speed of long recording time. Those extreme values obtained from observed data are considerably important to engineering applications. For instance, when the structure is under the condition of high

Paper Received November, 1996. Revised May, 1997. Accepted May, 1997. Author for Correspondence: Jing-Jong Jang.

*Associate Professor, Department of Harbor and River Engineering, National Taiwan Ocean University, Keelung, Taiwan, R.O.C.

**Graduate Student, Department of Harbor and River Engineering, National Taiwan Ocean University, Keelung, Taiwan, R.O.C. loads and low structural resistance, the way which the extreme wind speed values are recorded is very critical to its safety and liability. The maximum wind pressure, i.e. extreme-value wind speed, is the major variable to be considered for structural wind resistant design.

Thom [1,2] employed annual extreme-mile wind speed as samples to compile basic design wind speed distribution diagrams of different regression periods in U.S. areas. The extreme wind speed was Type II Extreme Value Distribution in hurricane areas and tropical monsoon areas.

Later, Simiu and other researchers $[3,4]$ found that Type I Extreme Value Distributions is more adequate under the only consideration of temperate air flow without consideration of hurricanes. The viewpoint brought up by Thom was noted of statistical sampling error. Therefore, Simiu, Bietry, and Filliben [5] complied Monte Carlo method in their research to avoid this kind of statistical sampling error caused by insufficient data. In 1980 Simiu, Batts, and Russell [6] analyzed again with Monte Carlo method to include the consideration of hurricane occurrence, and found out that the annual extreme value of wind speed is Weibull distribution if the average reading time is one minute. In the same year, Simiu and Filliben also adopted Monte Carlo method to analyze the distribution errors of different regression periods in areas without hurricane impact. They noted that no significant difference arised among all types of distribution models when the return period is short, while the difference becomes significant and the wind speed probability model matches better with Weibull distribution or Rayleigh distribution.

Therefore, this paper adopted the data of the annual fastest average wind speed with 10 minute recording time from 1951 to 1990 , recorded by 25 weather stations of Taiwan Central Weather Bureau as shown in Table 1, and followed up with analysis and discussion on probability distribution of wind speed. Furthermore, the basic design wind speed of 
different regression time period is determined within an acceptable probability for structural design.

\section{WIND SPEED DISTRIBUTION MODELS}

Wind speed probability distribution models are generally described by the following four common models: Type I Extreme Value Distribution, Type II Extreme Value Distribution, Weibull Distribution, and Rayleigh Distribution. They are as follows: Define: $\bar{U}=$ mean of wind speed, and $\sigma_{U}=$ standard deviation of wind speed.

\section{Type I Extreme Value Distribution}

This type of probability distribution is suitable in areas with mild condition and wind speed evenly distributed, and for longer interval of recording time, e.g. 10 minutes or one hour of average wind speed.

(1) Probability Density Function (P.D.F):

$$
\begin{aligned}
& f(U)=a \exp [-a(U-b)-\exp [-a(U-b)]], \\
& (-\infty<U<\infty, a>0, b<\infty) .
\end{aligned}
$$

(2) Cumulative Distribution Function (C.D.F):

$$
F(U)=\exp [-\exp [-a(U-b)]],
$$

Where $\bar{U} \approx b+\frac{0.577}{a}$,

$$
\sigma_{U}=\frac{\pi}{\sqrt{6} a} .
$$

After the means and standard deviation are determined by the annual fastest average wind speed form those weather stations, they can be applied to (3) and (4) to determine the values of $a$ and $b$.

\section{Type II Extreme Value Distribution}

This distribution is appropriate in areas with conditions of hurricanes or tropical monsoons, and for shorter interval of reading time, such as 2 to 3 seconds of speed or one minute of average wind speed.

(1) Probability Density Function (P.D.F):

$$
\begin{aligned}
& f(U)=\left(\frac{a}{b}\right)\left(\frac{b}{U}\right)^{a+1} \exp \left[-\left(\frac{b}{U}\right)^{a}\right], \\
& (U>0, a>0, b>0) .
\end{aligned}
$$

(2) Cumulative Distribution Function (C.D.F):

$$
F(U)=\exp \left[-\left(\frac{b}{U}\right)^{a}\right],
$$

$$
\begin{aligned}
& \text { where } \bar{U}=b \Gamma\left[1-\left(\frac{1}{a}\right)\right] \\
& \sigma_{U}=b\left\{\Gamma\left[1-\left(\frac{2}{a}\right)\right]-\Gamma^{2}\left[1-\left(\frac{1}{a}\right)\right]\right\}^{1 / 2} .
\end{aligned}
$$

Gamma Function $\Gamma(t)=\int_{0}^{\infty} x^{t-1} e^{-x} \mathrm{~d} x$.

\section{Weibull Distribution}

(1) Probability Density Function (P.D.F):

$$
\begin{aligned}
& f(U)=\left(\frac{a}{b}\right)\left(\frac{b}{U}\right)^{a-1} \exp \left[-\left(\frac{U}{b}\right)^{a}\right], \\
& (U>0, a>0, b>0) .
\end{aligned}
$$

(2) Cumulative Distribution Function (C.D.F):

$$
F(U)=1-\exp \left[-\left(\frac{U}{b}\right)^{a}\right],
$$

where $a$ and $b$ are denoted by Justus [7]. The definitions used in this study as follows:

$$
\begin{aligned}
& a=\text { Shape factor }=\left(\frac{\sigma_{U}}{\bar{U}}\right)^{-1.068}, \\
& b=\text { Scalar factor }=\frac{\bar{U}}{\Gamma(1+1 / a)} .
\end{aligned}
$$

\section{Rayleigh Distribution}

(1) Probability Density Function (P.D.F):

$$
f(U)=\frac{2 U}{b^{2}} \exp \left[-\left(\frac{U}{b}\right)^{2}\right] .
$$

(2) Cumulative Distribution Function (C.D.F) :

$$
\begin{aligned}
& F(U)=1-\exp \left[-\left(\frac{U}{b}\right)^{2}\right], \\
& \text { where } b=b=\frac{2 \bar{U}}{\sqrt{\pi}} .
\end{aligned}
$$

The accuracy of probability distribution can be ex-amined by goodness of fit test to determine whether this distribution is acceptable or shall be improved further. The statistic test methods adopted most are Chi-Square test and K-S (KolmogorovSmirnov) test [8]. The data used in this study are sampled from the annual fastest 10 -minute average wind speed recorded by twenty-five weather stations in Taiwan area from 1951 to 1990 . The number of data samples extracted from each station are various according to the station's establishment history. Table 1 presents those station's profiles. The fit tests are discussed as follows:

\section{Chi-Square Test}

This test examines the probability density func- 
Table 1. 25 Weather Stations of Taiwan Central Weather Bureau

\begin{tabular}{ccccrc}
\hline $\begin{array}{c}\text { Station } \\
\text { Name }\end{array}$ & $\begin{array}{c}\text { Year of } \\
\text { Commen } \\
\text { Cement }\end{array}$ & $\begin{array}{c}\text { North } \\
\text { Latitude }\end{array}$ & $\begin{array}{c}\text { East } \\
\text { Longitude }\end{array}$ & $\begin{array}{c}\text { Altitude } \\
(\mathrm{m})\end{array}$ & $\begin{array}{c}\text { Anemometer } \\
\text { Above Ground } \\
(\mathrm{m})\end{array}$ \\
\hline Tanshui & 1942 & $25^{\circ} 10^{\prime}$ & $121^{\circ} 26^{\prime}$ & 19.0 & 12.20 \\
Anpu & 1937 & $25^{\circ} 11^{\prime}$ & $121^{\circ} 31^{\prime}$ & 825.8 & 7.40 \\
Taipei & 1896 & $25^{\circ} 02^{\prime}$ & $121^{\circ} 30^{\prime}$ & 5.5 & 33.80 \\
Chutzehu & 1937 & $25^{\circ} 10^{\prime}$ & $121^{\circ} 32^{\prime}$ & 607.1 & 11.03 \\
Keelung & 1946 & $25^{\circ} 08^{\prime}$ & $121^{\circ} 44^{\prime}$ & 26.7 & 34.60 \\
Pengchiayu & 1909 & $25^{\circ} 38^{\prime}$ & $122^{\circ} 04^{\prime}$ & 101.7 & 7.20 \\
Hualien & 1910 & $23^{\circ} 59^{\prime}$ & $121^{\circ} 36^{\prime}$ & 16.1 & 10.00 \\
Suao & 1981 & $24^{\circ} 36^{\prime}$ & $121^{\circ} 52^{\prime}$ & 24.9 & 34.00 \\
Ilan & 1935 & $24^{\circ} 46^{\prime}$ & $121^{\circ} 45^{\prime}$ & 7.2 & 14.80 \\
Tungchitao & 1962 & $23^{\circ} 16^{\prime}$ & $119^{\circ} 40^{\prime}$ & 43.0 & 8.80 \\
Penghu & 1896 & $23^{\circ} 34^{\prime}$ & $119^{\circ} 33^{\prime}$ & 10.7 & 14.60 \\
Tainan & 1897 & $23^{\circ} 00^{\prime}$ & $120^{\circ} 12^{\prime}$ & 13.8 & 36.60 \\
Kaohsiung & 1931 & $22^{\circ} 34^{\prime}$ & $120^{\circ} 18^{\prime}$ & 2.1 & 14.00 \\
Chiayi & 1968 & $23^{\circ} 30^{\prime}$ & $120^{\circ} 25^{\prime}$ & 26.9 & 14.50 \\
Taichung & 1896 & $24^{\circ} 09^{\prime}$ & $120^{\circ} 41^{\prime}$ & 84.0 & 17.10 \\
Alishan & 1933 & $23^{\circ} 31^{\prime}$ & $120^{\circ} 48^{\prime}$ & 2413.4 & 15.10 \\
Tawu & 1940 & $22^{\circ} 21^{\prime}$ & $120^{\circ} 54^{\prime}$ & 8.1 & 12.70 \\
Yushan & 1943 & $23^{\circ} 29^{\prime}$ & $120^{\circ} 57^{\prime}$ & 3844.8 & 9.20 \\
Hsinchu & 1938 & $24^{\circ} 48^{\prime}$ & $120^{\circ} 58^{\prime}$ & 34.0 & 13.20 \\
Hengchun & 1896 & $22^{\circ} 00^{\prime}$ & $120^{\circ} 44^{\prime}$ & 22.3 & 14.30 \\
Chengkung & 1940 & $23^{\circ} 06^{\prime}$ & $121^{\circ} 22^{\prime}$ & 33.5 & 12.80 \\
Lanyu & 1941 & $22^{\circ} 02^{\prime}$ & $121^{\circ} 33^{\prime}$ & 324.0 & 12.50 \\
Jiyuehtan & 1941 & $23^{\circ} 53^{\prime}$ & $120^{\circ} 54^{\prime}$ & 1014.8 & 8.00 \\
Taitung & 1901 & $22^{\circ} 45^{\prime}$ & $121^{\circ} 09^{\prime}$ & 9.0 & 11.40 \\
Wuchi & 1976 & $24^{\circ} 16^{\prime}$ & $120^{\circ} 31^{\prime}$ & 7.2 & 33.20 \\
\hline & & & & & \\
\hline
\end{tabular}

tion with interval number $k$ to determine whether the observed frequencies $n_{1}, n_{2}, \ldots \ldots . ., n_{k}$ and the theoretic frequencies $e_{1}, e_{2}, \ldots \ldots . ., e_{k}$ are closely match each other. If the theoretic probability density functions satisfy the following statement:

$$
\sum_{i=1}^{k} \frac{\left(n_{i}-e_{i}\right)^{2}}{e_{i}}<C_{1-\alpha, f},
$$

where $C_{1-\alpha, f}=x_{f}^{2}$ is the value related to the value (1$\alpha)$ of its distribution,

$f=$ degree of freedom (d.o.f)

$=k-1$ (number of undetermined parameters in theoretic probability density function).

Then, the theoretic probability density function can be considered as an acceptable model within significance level $\alpha$.

The most common significance levels are 5\% and $1 \%$. They can be chosen as required, even outside the range of $5 \%$ and $1 \%$. Neither Chi-Square test nor K-S test can provide absolute compatibility between probability distribution and the actual data.
For instance, a probability distribution may be acceptable for one significance level; meanwhile, it may not be acceptable for another significance level.

The grouping of wind speed data [5] in this study is based on the mean of annual fastest 10 minute average wind speed $\bar{U}$, and class interval $\Delta U$, which is one fourth of standard deviation $\sigma_{U}$ of annual fastest wind speed, that is $\Delta U=\sigma_{U} / 4$. The interval number $\mathbf{k}$ of wind speed data shall be determined by expanding distance of $\Delta U$ toward both left and right directions as required.

The degree of freedom depends on the grouping of wind speed data and the undetermined parameters in theoretic probability density function. In Type I Extreme Value distribution, Type II Extreme Value distribution, and Weibull distribution, the parameters are determined by mean values and standard deviations of data. Therefore, the degree of freedom for the above types of distribution shall be subtracted by 2 for computation. In Rayleigh distribution, the parameter is only detiermined by mean values of data. Therefore, its degree of freedom is subtracted by 1 . 
The Chi-Square test of the data obtained from twenty-five weather stations of Central Weather Bureau in Taiwan area is performed. According to the results [9], Type I Extreme Value distributions is more adequate for both $5 \%$ and $1 \%$ significance levels for most of the stations in Taiwan area.

\section{K-S Test}

K-S test checks the cumulative distribution function and it compares the difference between test cumulative distribution and theoretic cumulative distribution function. The theoretical model isl not accepted unless this difference is less than certain level.

For a data set of sample number $\mathrm{n}$, the sample values can be compiled into a stepped cumulative frequency curve by sorting data in an ascendant order. They are indicated as follows:

$$
S_{n}(x)= \begin{cases}0 & , x<x_{1} \\ \frac{n}{k} & , x_{k} x<x_{k+1}, \\ 1, & x \geq x_{n}\end{cases}
$$

where $x_{1}, x_{2} \ldots \ldots, x_{n}=$ sample value in ascendant order.

The difference between test cumulative frequency curve $S_{n}(x)$ and theoretic cumulative distribution function $F(x)$ can be calculated. The maximum error between $S_{n}(x)$ and $F(x)$ in full range of random variable $\mathrm{x}$ will be used to evaluate the difference between theoretic model and observed data. Assume that the maximum error to be $D_{n}$ is

$$
D_{n}=\max _{x}\left|F(x)-S_{n}(x)\right| .
$$

$D_{n}$ is a random variable and its distribution shall be relative to sample number $n$. For K-S test under significance level $\alpha$, the $D_{n}$ maximum error $D_{n}{ }^{\alpha}$ determined from Eq. (18) will be compared with critical value which is defined as the following:

$$
P\left(D_{n} \leq D_{n}{ }^{\alpha}\right)=1-\alpha .
$$

The value of $D_{n}{ }^{\alpha}$ of various $\mathrm{n}$ values under significance level $\alpha$ can be determined from K-S test results.

The theoretic mathematical model is acceptable if maximum tested error is less than critical value $D_{n}{ }^{\alpha}$ under significance level $\alpha$; otherwise, it is rejected. Those results indicate that all four cumulative distribution functions are acceptable for most of weather stations in Taiwan area. However, Type I Extreme Value distribution is more appropriate because its mean value of maximum error is less than those of the other three.

\section{CALCULATION OF DESIGN WIND SPEED}

Basic design wind speed is defined as $\mathrm{U}(10, \mathrm{C})$ with recording station of 10 -meter elevation, and ground condition $\mathrm{C}$ where station is assumed to be located at flat and plain and the height of scattered obstructions is less than $\mathbf{1 0}$ meters. The anemometer elevations and ground conditions of those Central Weather Bureau's recording stations do not correlate with such a definition. Therefore, the defined value of basic wind speed will be adjusted by Power law.

Professor Tsai [10] analyzed basic wind speed of those station by sampling maximum 10-minute average wind speed and maximum 2 to 3 second gust speed of 98 typhoons attacking Taiwan during 1947 and 1980 , recorded by 24 weather stations of Central Weather Bureau. He assumed that typhoons are Poisson process since each typhoon is a discrete random variable, and computed wind speed of each regression period through Poisson process. Therefore, the data obtained from each typhoon are accessible for implementation purposes.

This study adopts theories of extreme value statistics [8] to analyze basic design wind speed. Since prediction of future conditions is required for a structure's planning and design processes, the theory of extreme value statistics is a facilitative tool for engineer to predict the maximum and minimum values from observed extreme value data. Due to the consideration that structure design is based on the structure's extreme condition, the authors used the annual maximum 10-minute average wind speed, recorded by 25 weather stations of Central Weather Bureau during 1951 and 1990, as samples in this study. Those lower wind speed data can be omitted to avoid sampling deviation.

According to the discussion in previous section, Type I Extreme Value distribution is more ap propriate as annual maximum wind speed probability distribution in Taiwan area for sampling annual maximum 10- minute average wind speed. Also, as previously, extreme value statistics is unitized to analyze basic wind speed of different regression periods. Therefore, exceedance probability theory and method of moments is applied to calculate the basic wind speed with $10 \%$ exceeding probability in 50 years and basic wind speed of different return periods in Taiwan area.

\section{Exceedance Probability Theory}

The importance of extreme values is to predict 
future exceedance possibility of previous observed data. This predication has to be indicated by probability. Usually, the distribution functions of previous and future observed values are known, such as the extreme value distributions of annual maximum flood flow or annual maximum wind speed. Under this circumstance, these distribution information can be utilized to determine required exceedance probability. Assume that $X$ is the initial random variable when the initial distribution function $F_{x}(x)$ is known. The maximum cumulative distribution function with sample number $\mathrm{n}$ out of $\mathrm{X}$ shall be indicated as the following:

$$
F_{X_{n}}(x)=\left[F_{X}(x)\right]^{n}
$$

If initial distribution function $F_{x}(x)$ has the form as Type I Extreme Value distribution, as indicated in Eq. (2), then the maximum cumulative distribution function of $n$ sample out of $X$ is:

$$
F_{X_{n}}=\exp \left[-\exp \left[-a\left(x-b-\frac{\ln n}{a}\right)\right]\right] .
$$

If $y_{n}$ denotes the maximum value among $\mathrm{n}$ observed values $\left(x_{1}, x_{2}, \ldots ., x_{n}\right)$, that is,

$$
y_{n}=\max \left(x_{1}, x_{2}, \ldots \ldots, x_{n}\right) .
$$

It can be applied from sample number size $\mathrm{n}$ and $F_{X}\left(y_{n}\right)=1-\frac{1}{n}$, meaning $y_{n}$ is the best estimated value of $b_{n}$. Let $b_{n}=y_{n}$, the maximum distribution among future $\mathrm{N}$ observed sample number is

$$
\begin{aligned}
& F_{X_{N}}(x)=\left[F_{X}(x)\right]^{\mathrm{N}} \\
& =\left\{\left[F_{X}(x)\right]^{n}\right\}^{\frac{N}{n}} \\
& =\exp \left[-\frac{N}{n} e^{-a\left(x-y_{n}\right)}\right] \\
& =\exp \left[-e^{\ln \frac{N}{n}} e^{-a\left(x-y_{n}\right)}\right], \\
& F_{X_{N}}=\exp \left[-\exp \left[-a\left(x-y_{n}-\frac{\ln \frac{N}{n}}{a}\right)\right]\right]
\end{aligned}
$$

$F_{X_{N}}(x)$ is also identified as Type I Extreme Value distribution, and its parameters are

$$
\left\{\begin{array}{l}
a_{N}=a, \\
b_{N}=y_{n}+\frac{\ln (N / n)}{a} .
\end{array}\right.
$$

If $y_{n}$ denotes the maximum value among $\mathrm{n}$ previous observed values, then the maximum distribution among $\mathbf{N}$ future observed values can be determined by Eq. (21). Therefore, the probability that maximum value among $\mathrm{N}$ future observed values will exceed that $\mathbf{n}$ previous observed values, i.e.

$$
\begin{aligned}
& \operatorname{Pr}\left(X_{N}>y_{n}\right)=1-\exp \left[-\exp \left[-a\left(y_{n}-y_{n}-\frac{\ln \frac{N}{n}}{a}\right)\right]\right] \\
& \Rightarrow \operatorname{Pr}\left(X_{N}>y_{n}\right)=1-\exp \left[-\frac{N}{n}\right] .
\end{aligned}
$$

On the other hand, if probability $p$ is that maximums value among $\mathrm{N}$ future observed values will exceed previous maximum has been determined, then the design values $X_{N}$ can be determined from the following:

$$
\begin{aligned}
& p=1-\exp \left[-\exp \left(-\alpha\left(X_{N}-y_{n}-\frac{\ln \frac{N}{n}}{a}\right)\right]\right], \\
& X_{N}=y_{n}+\frac{1}{a}\left[\ln \frac{N}{n}-\ln \ln \frac{1}{(1-p)}\right] .
\end{aligned}
$$

After the annual maximum 10-minute average wind speed during 1951 and 1990 was sampled from twenty-five weather stations, the design wind speed at each station in the future 50 years can be determined by Eq. (23), and the basic design wind speed with exceedance probability $10 \%$ in 50 years can be converted by the following:

$$
U(10, C)=0.6 U(Z, x)\left(\frac{Z g(x)}{Z}\right)^{\alpha(x)},
$$

where $x=1,2,3,4$ each indicates ground condition A,B,C,D.

Z: elevation,

$\mathrm{Z}_{\mathrm{g}}$ : elevation of gradient,

$C$ : roughness of ground surface,

$\alpha$ : coefficient of power law.

The basic design wind speed can be analyzed by exceedance probability theory corresponding to the ground conditions of each weather stations [9]. The 50-year return period basic design wind speed distribution diagram of Taiwan area as shown in Fig. 1.

\section{Method of Moments}

In general, extreme value data are difficult to obtain primarily because they require a great amount of time and resources to collect. For instance, the sample size of annual maximum wind speed only increase one more annually, and for strong earthquakes (Richter scale $M \geq 5.0$ ), it may require even more years to observe. In other words, the sample size of extreme value data is usually very limited. Therefore, for estimating parameters of extreme value distribution, an appropriate estimation method can be selected for sampling or collecting data. The accuracy of estimation process is extremely critical when obtained data are limited.

Limited sample number is considered into the analysis results when statistic sampling and estima- 
tion are involved in process. Several methods are available to estimate parameters of unknown original distribution. Ideally, estimated value shall be of unbiasness and variance shall be as small as possible. Parameter estimation includes determination of adequate sample moment for estimated data, including sample mean $\bar{x}$ and sample variance $\sigma_{x}^{2}$, sometimes, even including third power moment or skewness.
Then parameters can be estimated on the basis of the relationship between parameters themselves and sample moments.

The method of moments is implemented to estimate the parameters of Type I Extreme Value distribution, wind speed of $\mathrm{N}$-year return period, $U_{N}$ [11], and its confidence intervals can be calculated as following:

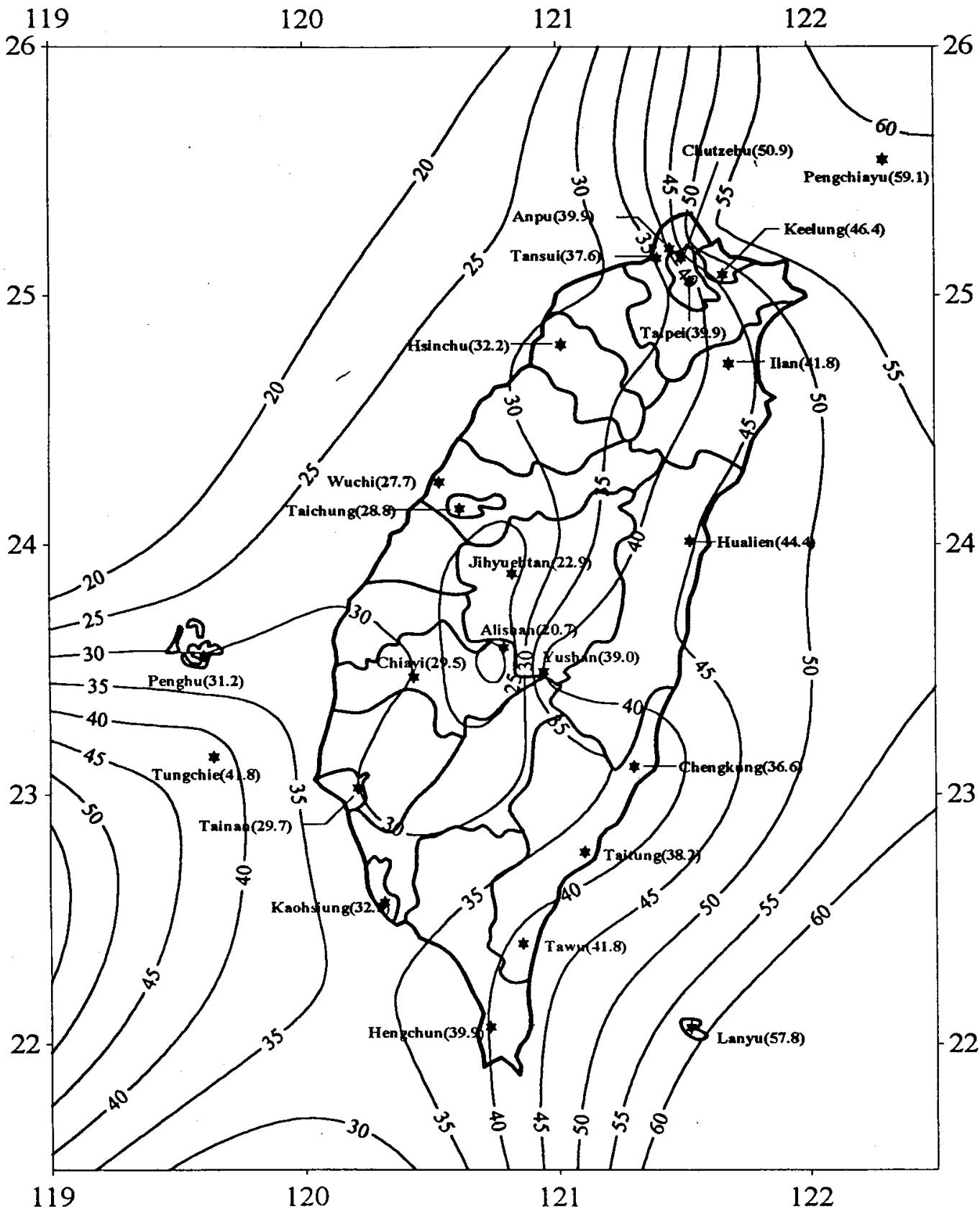

Fig. 1. Map of Design Wind Speed with 50 Years Return Period. 
Table 2. Basic Design Wind Speed of Different Return Period

\begin{tabular}{|c|c|c|c|}
\hline Station & 25 Years Return & 50 Years Return & 100 Years Return \\
\hline Name & Period $(\mathrm{m} / \mathrm{sec})$ & Period $(\mathrm{m} / \mathrm{sec})$ & Period $(\mathrm{m} / \mathrm{sec})$ \\
\hline Taipei & 35.85 & 39.87 & 43.88 \\
\hline Alishan & 18.79 & 20.74 & 22.68 \\
\hline Hengchun & 36.51 & 39.85 & 43.16 \\
\hline Anpu & 36.56 & 39.87 & 43.14 \\
\hline Chengkung & 33.05 & 36.61 & 40.14 \\
\hline Hsinchu & 29.11 & 32.23 & 35.31 \\
\hline Tanshui & 34.10 & 37.59 & 41.06 \\
\hline Chutzehu & 45.54 & 50.85 & 56.10 \\
\hline Keelung & 41.95 & 46.35 & 50.73 \\
\hline Pengchiayu & 53.54 & 59.10 & 64.61 \\
\hline Hualien & 39.27 & 44.37 & 49.42 \\
\hline Ilan & 37.05 & 41.83 & 46.56 \\
\hline Kaohsiung & 29.75 & 32.54 & 35.32 \\
\hline Tainan & 27.24 & 29.74 & 32.22 \\
\hline Taichung & 26.10 & 28.84 & 31.58 \\
\hline Tawu & 38.20 & 41.80 & 45.37 \\
\hline Penghu & 28.68 & 31.21 & 33.72 \\
\hline Jiyuehtan & 21.06 & 22.88 & 24.69 \\
\hline Taitung & 33.68 & 38.16 & 42.61 \\
\hline Lanyu & 53.44 & 57.78 & 62.10 \\
\hline Yushan & 36.40 & 38.95 & 41.49 \\
\hline Tungchitao & 38.66 & 41.76 & 44.84 \\
\hline Chiayi & 26.90 & 29.46 & 32.02 \\
\hline Wuchi & 26.05 & 27.70 & 29.35 \\
\hline Suao & 21.32 & 23.20 & 25.07 \\
\hline
\end{tabular}

$$
U_{N}=\bar{U}+\sigma_{U}(y-05772)^{\frac{\sqrt{6}}{\pi}},
$$

where $y=-\ln \left[-\ln \left(1-\frac{1}{N}\right), \bar{U}\right.$ and $\sigma_{U}$ can be determined from Eq. (3) and (4).

According to the consideration of sampling errors when computing parameters with Method of Moments, standard deviation of $\mathrm{N}$-year return period wind speed $\sigma_{s e}\left(U_{N}\right)$ will be calculated by the following Eq.., that is,

$$
\begin{aligned}
\sigma_{s e}\left(U_{N}\right) & =\left[\frac{\pi^{2}}{6}+1.1396(y-0.5772) \frac{\pi}{\sqrt{6}}\right. \\
& \left.+11(Y-05772)^{2}\right]^{1 / 2 \frac{\sqrt{6}}{\pi} \frac{\sigma_{U}}{\sqrt{n}}}
\end{aligned}
$$

where $n=$ sample number and the standard deviation can be estimated by another theory, which is known as Cramer-Rao lower bound, as follows:

$\sigma_{C R}\left(U_{N}\right)=\left[060793 y^{2}+051404 y+110866\right]^{1 / 2 \frac{\sqrt{6}}{\pi}} \frac{\sigma_{U}}{\sqrt{n}}$.

The relationship between confidence intervals and confidence levels is as follows:

\section{Confidence Level $68 \%$ :}

Method of Moments $U_{N} \pm s_{S E}\left(U_{N}\right)$; Lower Bound $\mathrm{U}_{\mathrm{N}} \pm \mathrm{s}_{\mathrm{CR}}\left(\mathrm{U}_{\mathrm{N}}\right)$.

\section{Confidence Level 95\%:}

Method of Moments $U_{N} \pm 2 s_{S E}\left(U_{N}\right)$;

Lower Bound $\mathrm{U}_{\mathrm{N}} \pm 2 \mathrm{~s}_{\mathrm{CR}}\left(\mathrm{U}_{\mathrm{N}}\right)$.

\section{Confidence Level 99\%:}

\section{Method of Moments $U_{N} \pm 3 s_{S E}\left(U_{N}\right)$;} Lower Bound $U_{N} \pm 3 s_{C R}\left(U_{N}\right)$.

Basic design wind speed of different return period is calculated and depicted in Table 2. Proportional relationship between $\mathrm{N}$-year return period wind speed and its standard deviation can be calculated. The design Wind speed with $10 \%$ possibility of being exceeded in 50 years of Taiwan area as shown Fig. 2.

\section{RESULTS AND DISCUSSIONS}

This study began with discussions regarding wind speed characteristics and distribution probability models of Taiwan area and followed by Chi-Square test and K-S test analysis. According to the previous discussions and analysis, the results shows that Type I Extreme Value distribution is more appropriate for wind speed probability distribution in Taiwan area than Type II Extreme Value distribution, Weibull distribution, and Rayleigh distribution.

It should be noted that Chi-Square test and K-S test do not provide absolute suitability for probability distribution model and actual data. For instance, a probability distribution model may be accepted under one significance level, while it may not be acceptable under another significance level. The grouping of wind speed data for Chi-Square test is based on the mean of annual maximum 10-minute average wind speed. One quarter of annual maximum wind speed standard deviation was determined as class interval $\Delta U$, that is $\Delta U=\sigma_{u} / 4$ with coverage toward right and left, in order to determine interval number $\mathrm{k}$ required for wind speed data. K-S test indicates that four cumulative distribution functions generally satisfy the analysis. However, Type I Extreme Value distribution has the least mean value of maximum recording errors among all probability distributions. To avert sampling errors during the test analysis, the wind speed data recorded by Suao station were omitted to analyze because of its limited 
sample number of nine.

The main purpose of this study is to develop the basic design wind speed for structure wind-resistant design in Taiwan area. Usually, most of the structure were design with an expected usage life of 50 years. Therefore, 100 years or more usage life is expected for the important or official structures and 25 years or less usage life is expected for less important or temporary structures. Table 2 shows the recommendations of basic design wind speed with 25,50 and 100 years regression return period of Taiwan area according to the probability theory. It is noted that the difference of design wind speed between 25,50 and 100 years return period is relative small, which is about or less than $10 \%$.

Figures 1 and 2 provide the basic design wind

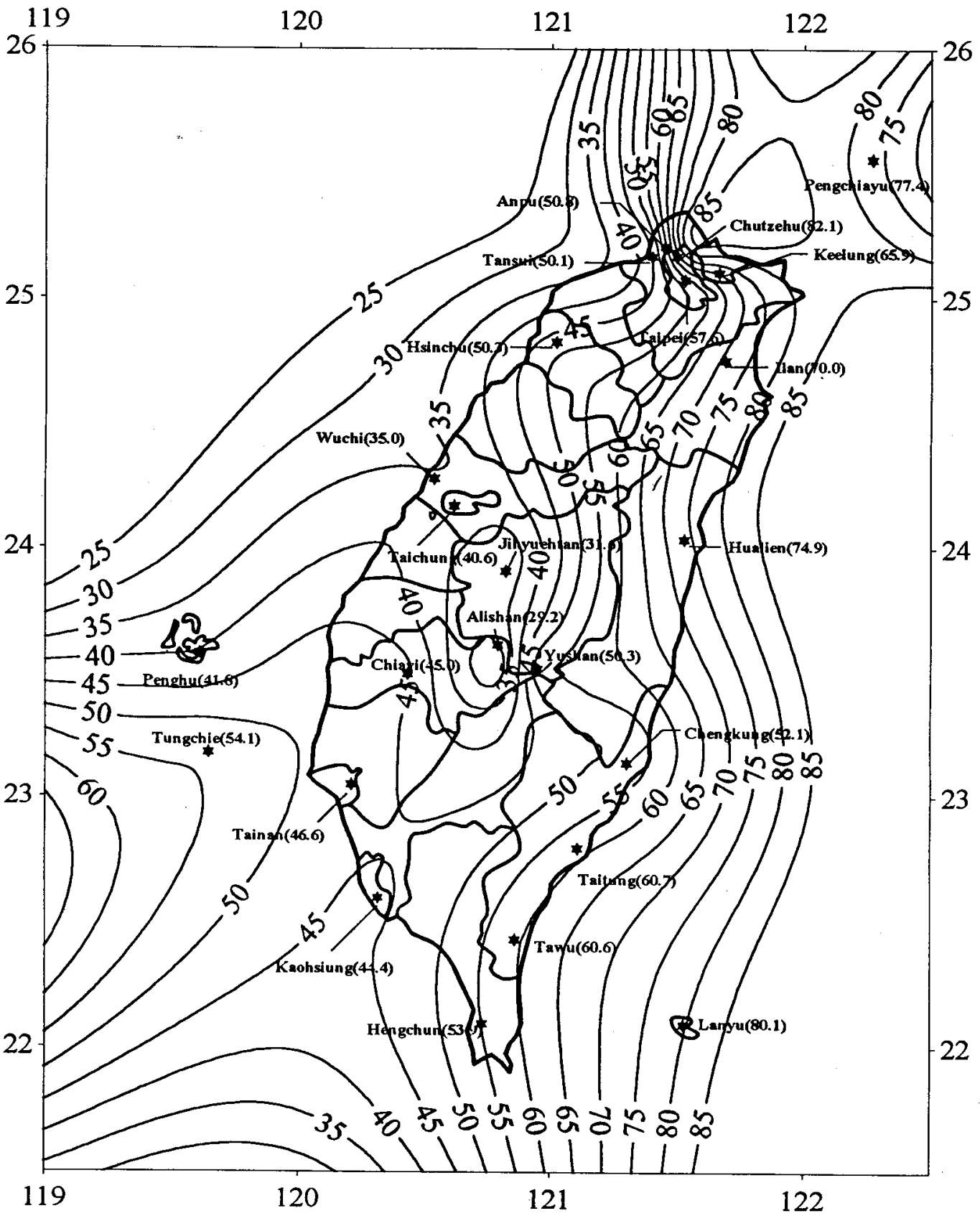

Fig. 2. Design Wind Speed with $10 \%$ Execeedence Probability in 50 Years. 
speed distribution map in Taiwan area with 50 years of return period and with an exceedance probability $10 \%$ during 50 -year usage, which is equivalent to 475 years of return period, based upon exceedance probability theory. It is noted that the recommendations of design wind speed in Fig. 2 is larger and much more conservative than the design wind speed in Fig. 1 and they can be applied to a variety of windresistant structure design in Taiwan area.

\section{ACKNOWLEDGMENT}

The authors would like to thank the National Science Council for its support of this research (NSC 84-2211-E-019-001)

\section{REFERENCES}

1. Thom, H.C.S., "Distributions of Extreme Winds in the United States," Journal of the Structural Division, ASCE, Vol. 86, No. 4, pp. 11-24 (1960).

2. Thom, H.C.S., "New Distributions of Extreme Winds in the United States," Journal of the Structural Division, ASCE, Vol. 94, No. 7, pp. 1787-1801 (1968).

3. Simiu, E. and Filliben, J.J., "Probability Distribution of Extreme Wind Speeds," Journal of the Structural Division, ASCE, Vol. 100, No.9, pp.1861-1877(1974).

4. Simiu, E. and Filliben, J.J.,"Weibull Distributions and Extreme Wind Speeds," Journal of the Structural Division, ASCE, Vol. 106, No. 12, pp. 2365-2374 (1980).

5. Simiu, E., Bietry, J. and Filliben, J.J., "Sampling Errors in estimation of Extreme Winds," Journal of the Structural Division, ASCE, Vol. 104, No. 3, pp. 491-501 (1978).

6. Simiu, E., Batts M.E., and Russell, L.R., "Hurricane Wind Speeds in the U.S.," Journal of the Structural Division, ASCE, Vol. 106, No. 10, pp. 2001-2016 (1980).

7. Justus, G.G., "Methods for Estimating Wind Speed
Frequency Distributions," Journal of Applied Meteorology, Vol. 17, pp. 350-353 (1977).

8. Ang, A.H-S. and Tang, W.H., Probability Concepts in Engineering Planning and Design, Vol.I-Basic Principles, John Wiley and Sons Inc., (1984).

9. J.J. Jang and Lee, J.R., "Analysis of Wind Speed Distribution Model of Taiwan Area," Proceedings of Conference on Computer Application in Civil \& Hydraulic Engineering, (1995).

10. Y.C. Tsai and Lin, J.C., "Analysis of Structure Wind Loading in Taiwan Building Code," National Science Council Report R. O. C., ANEC73 - 0414 - P002-04, (1984).

11. Simiu, E. and Scanlan, R.H., Wind Effects on Structures, 2nd Edition, John Wiley and Sons Inc., New York, (1986).

\section{台灣地區設計風速分佈之分析}

\section{張 景 鐘 李 政 儒}

國立台沙海洋大學河海工程系

摘 要

本文主要針對台灣地區風力载重規籁中, 基 本設計風速做深入的探討。首先以Chi-Square試验 法與K-S 試驗法, 對四種常用的風速或然率分佈模 式即型I極值分佈、型II極值分佈、Weibull分佈及 Rayleigh分佈, 利用喜灣地區中央氧象局所屈25個 氣象测站於1951至1990年間所測得之每年最大十分 鐘平均風速為樣本作試驗, 結果以型I極值分佈最通 合薹裂地區風速分佈。最後, 本文採用超值或然率 理論及矩法, 來探討毫灣地區 50 年超越機率基本設 計風速與迥歸期基本設計風速, 並繪出台灣地區50 年回歸期之基本風速分佈圆與 50 年超越機率 $10 \%$ 之 基本風速分佈圖, 可以提供結構風力設計和未来相 關風力規籁修正之參考。 